Review article

\title{
Causes and distribution of soil pollution in China
}

\author{
Claudio O. Delang \\ Department of Geography, Hong Kong Baptist University, Kowloon Tong, Hong Kong \\ E-mail address: cdelang@hkbu.edu.hk
}

\begin{abstract}
China is the most populated country in the world, but has relatively little fertile land, and even less water. Maintaining the quality of its agricultural land is of paramount importance if China wants to feed its very large and growing population. Yet, China is one of the countries with the largest amount of polluted soil. This paper looks at the causes and distribution of soil pollution in China. It first looks at the amount of organic and inorganic soil pollutants and their geographic distribution. It then looks at the causes of soil pollution, making the distinction between agricultural activities, industrial activities, and urbanization. Pollution from agricultural activities stems primarily from the excessive amounts of pesticides and fertilizers used on farmland, and is mainly located in the south, where most of the food is produced. Pollution from industrial activities is due to airborne industrial pollutants that fall on to the land, and is mainly located in the west of the country, where most manufacturing activities take place. Pollution from urbanization is mainly due to the very large amount of solid, liquid and gaseous waste generated in a small area with insufficient treatment facilities, and exhaust fumes from vehicles, and is located around the largest cities, or roads. The result is that one fifth of China's farmland is polluted, and an area the size of Taiwan is so polluted that farming should not be allowed there at all.
\end{abstract}

KEY WORDS: soil pollution, pollutants, heavy metals pollution, wastewater pollution, China

ARTICLE HISTORY: received 13 November 2017; accepted 8 December 2017

\section{Introduction}

The problem of soil degradation, in particular soil erosion, is not unknown to Chinese people. In Northern China, people have long been suffering from dust storms from the arid Loess Plateau, a problem which the government started to address in the 1980s through a series of environmental conservation programs. In the late 1990s the government also initiated the largest forest conservation and reforestation programs in the world, in most of the central and western provinces (DELANG \& YUAN, 2015). The problem and the extent of soil pollution are not well known in China. People do know that not all the food they eat is healthy, but they do not know the scale of the problem. Indeed, up until very recently, little was known of the true extent of soil pollution in China, since the government has consistently refused to make comprehensive soil pollution data public.
In 2013, Beijing's lawyer Dong Zhengwei requested soil pollution data from the Ministry of Environmental Protection, including information on the causes and methods for dealing with the problem. The request was declined on the grounds that the data was a "state secret". Nevertheless, at the end of 2013, the government released limited information on soil pollution, partly because of the strong public reaction against that refusal. Despite the lack of details, the released data caused widespread concern (HE, 2014a). In April 2014, the government issued a more comprehensive report about the country's soils (HE, 2014b). The report shows that $16.1 \%$ of the soil samples (19.4\% for agricultural soils) are contaminated with organic and chemical contaminants, as well as heavy metals and metalloids such as lead, cadmium, and arsenic (ZHAO ET AL., 2015). Chinese officials say that an area the size of Taiwan is so polluted that farming should not be allowed there 
at all (WONG, 2014). In this paper, I first describe the amount and geographic distribution of inorganic and organic pollutants in soils. I then look at the sources of pollution, dealing in turn with agricultural activities, industrial activities, and urbanization.

\section{Amount and geographic distribution of heavy metals in soils}

Contaminated soils with high amounts of heavy metals (for example cadmium [Cd], chromium [Cr], and lead $[\mathrm{Pb}]$ ) can set off a phototoxic reaction in plants, decreasing crop yields. Moreover, the roots of plants can absorb these heavy metal pollutants, which accumulate in the crops and damage the health of the people who eat them. The bioaccumulation of heavy metals in the body can lead to severe health issues including abnormalities of the skeletal system, lung diseases, and cancers (LIU ET AL., 2016).

According to a 2014 survey on the heavy metal and metalloid contamination of soil, in China 16.1\% of the sampled land was contaminated by mercury $(\mathrm{Hg})$, arsenic (As), cadmium (Cd), and lead (Pb); agricultural lands were primarily polluted by mercury, arsenic, cadmium, lead, copper (Cu), DDT, nickel (Ni), and polycyclic aromatic hydrocarbons; grasslands, forests, and unused lands were primarily affected by arsenic, cadmium, and nickel pollution. Cadmium ranked highest with $7 \%$ of the soil samples being polluted, followed by nickel (4.8\%), arsenic (2.7\%), copper (2.1\%), and mercury $(1.6 \%)$ (Table 1). Inorganic pollutants also exceed standards, although not to the extent of organic pollutants (ZHAO ET AL., 2015).

Table 1. Amount of land polluted with inorganic and organic pollutants (Source: MEP, 2014)

\begin{tabular}{|c|c|c|c|c|c|}
\hline \multirow[t]{2}{*}{ Pollutant } & \multirow{2}{*}{$\begin{array}{l}\% \text { of land } \\
\text { polluted }\end{array}$} & \multicolumn{4}{|c|}{ Degrees of exceedance (\%)* } \\
\hline & & Light & Mild & Moderate & Severe \\
\hline \multicolumn{6}{|c|}{ Inorganic pollutants } \\
\hline Cadmium & 7.0 & 5.2 & 0.8 & 0.5 & 0.5 \\
\hline Nickel & 4.8 & 3.9 & 0.5 & 0.3 & 0.1 \\
\hline Arsenic & 2.7 & 2.0 & 0.4 & 0.2 & 0.1 \\
\hline Copper & 2.1 & 1.6 & 0.3 & 0.15 & 0.05 \\
\hline Mercury & 1.6 & 1.2 & 0.2 & 0.1 & 0.1 \\
\hline Lead & 1.5 & 1.1 & 0.2 & 0.1 & 0.1 \\
\hline Chromium & 1.1 & 0.9 & 0.15 & 0.04 & 0.01 \\
\hline Zinc & 0.9 & 0.75 & 0.08 & 0.05 & 0.02 \\
\hline \multicolumn{6}{|c|}{ Organic pollutants } \\
\hline Dichlorodiphenyltrichloroethane & 1.9 & 1.1 & 0.3 & 0.25 & 0.25 \\
\hline Polyaromatic hydrocarbons & 1.4 & 0.8 & 0.2 & 0.2 & 0.2 \\
\hline Hexachlorocyclohexane & 0.5 & 0.3 & 0.1 & 0.06 & 0.04 \\
\hline
\end{tabular}

* Soil pollution is divided into five classes according to degree: soils with a pollutant level that does not exceed the quality standard are viewed as non-polluted; soils with levels that are not more than 2 times the maximum are viewed as being polluted lightly; soils with levels that are between 2 and 3 times the maximum are mildly polluted; soils with levels between 3 and 5 times the maximum are moderately polluted; and soils with levels that are more than 5 times the maximum are severely polluted (MEP, 2014)

ZHANG ET AL. (2016a) emphasized the importance of calculating the amount, origin, and spatial distribution pattern of heavy metals in soils, to establish quality standards for the different regions and estimate the potential impact of soil pollution on food safety and human health.

\subsection{Distribution of cadmium in soils}

Cadmium (Cd) is the most commonly found soil contaminant of all heavy metals in China. LI ET AL. (2016) argue in that in the surface dust of cities,
Cd mainly originates from tire wear, engine oils, coal combustion, waste treatment, the metal finishing industries, and the production and application of pesticides and fertilizers. Many provinces have Over Limit Sites (OLSs) (Fig. 1), but they are most prevalent in the provinces of Guizhou (Fig. 1E) and Hunan (Fig. 1F), and south of the Yangtze River. Field surveys conducted by WANG ET AL., (2016) in eight towns in Youxian (Hunan Province) showed that in $90 \%$ of the study area the Cd content in the soil of rice paddies exceeded the permissible limit of $0.3 \mathrm{mg} \mathrm{kg}^{-1}$, averaging $0.228-1.91 \mathrm{mg} \mathrm{kg}^{-1}$. 
The highest distribution was found at Weining (Guizhou Province), home to the world's largest germanium mine. Cadmium OLSs were also found in Shandong, Henan, and Tianjin (Fig. 1D), all of which are densely populated regions with significant economic activities, as well as the Liaodong Peninsula in north-east China (Fig. 1C), a major heavy metal industrial region. The highest cadmium concentration $(578 \mathrm{mg} / \mathrm{kg}$, hundreds of times more than the allowed amount) can be found in the soils of Lanping County (Yunnan Province), close to the massive lead-zinc deposit in Jinding (DUAN ET AL., 2016).

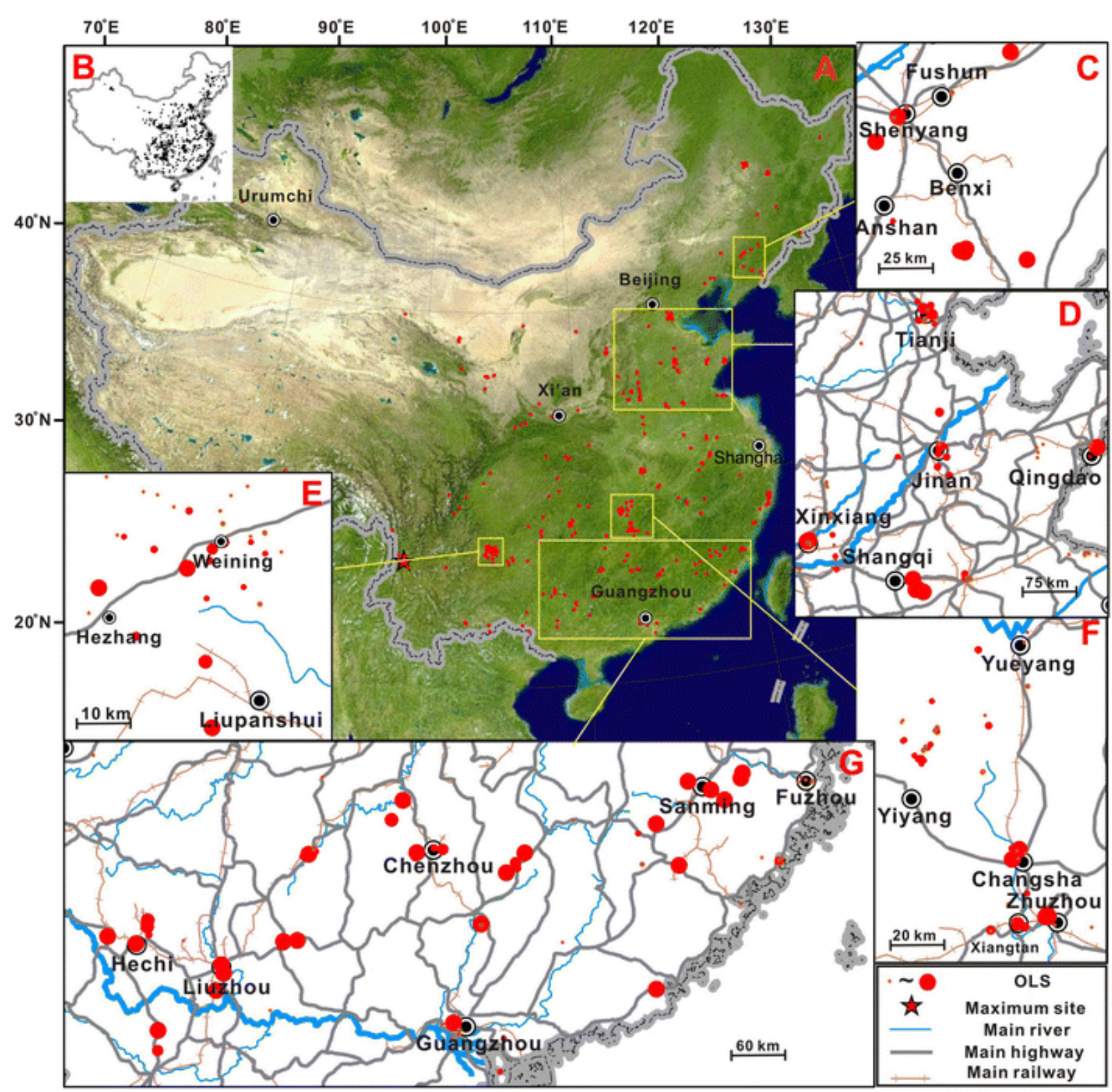

Fig. 1. China's distribution of cadmium Over Limit Sites (OLSs) (A); Distribution of cadmium sampling sites (B-G) (Source: Duan et al., 2016)

Note: In (C) (D) (E) (F) and (G), Over Limit Sites (OLSs, red dots) were grouped into 4 classes: 1-3, 3-5, 5-10, and $>10$ according to the multiples of the limit value $(\mathrm{Cd}: 1 \mathrm{mg} / \mathrm{kg})$

\subsection{Distribution of lead in soils}

High levels of lead $(\mathrm{Pb})$ are another major threat to ecological and human health (LI ET AL., 2016). Sources of lead emission include engine oil, vehicle exhaust, tire wear, bearings, smelting, and oil products. Many cities in southern China are facing an acute lead contamination crisis. Two economically and demographically significant conurbations, Shanghai (Fig. 2E) and Guangzhou (Fig. 2G), have particularly high concentrations of lead in their soil. Hezhang County in Guizhou Province (Fig. 2F), important for its lead and zinc mines, also shows dense lead OLSs. According to the available data, the highest density of lead in the soils in China $(30,430 \mathrm{mg} / \mathrm{kg})$ was found in Sanming, in close 
proximity to a lead and zinc smelting facility (Fig. 2G) (DUAN ET AL., 2016).

While fewer and lower density lead OLSs occurred in northern China than in southern and eastern China, there are still a number of places with relatively high concentrations. As an example, the Liaodong Peninsula in north-east China (Fig. 2D), as well as the strip of land between Chengxian
(Gansu Province) and Xi'an (Shaanxi Province) (Fig. 2C) have relatively high concentrations of lead OLSs. This is attributable to the geographical location of Chengxian, which sits in the prominent lead-zinc mineral belt of Xihe-Chengxian, where a massive mining zone has been excavated since the Ming Dynasty (DUAN ET AL., 2016).

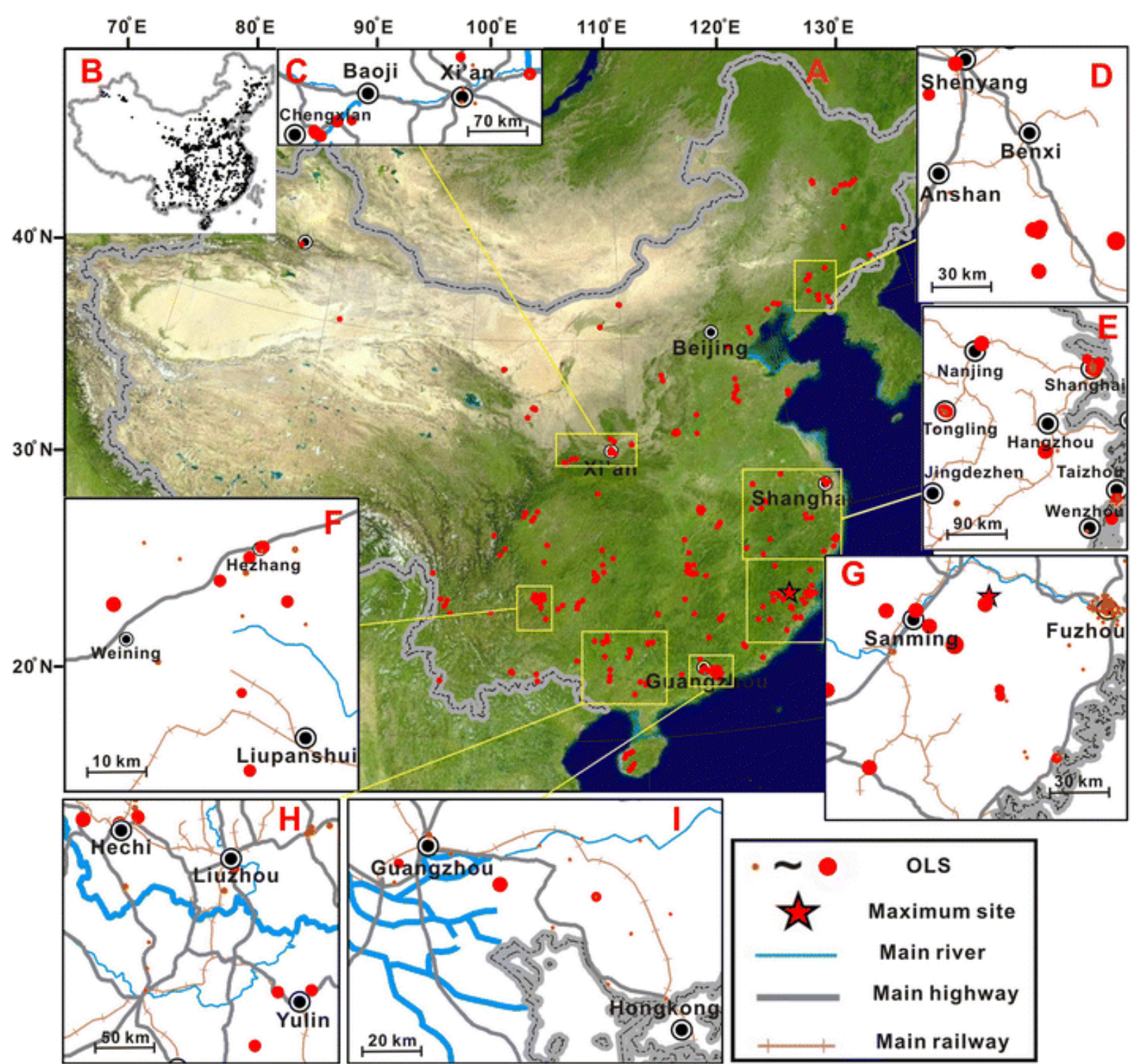

Fig. 2. China's distribution of lead Over Limit Sites (OLSs) (A); Distribution of lead sampling sites (B-I) (Source: Duan et al., 2016)

Note: In (C) (D) (E) (F) (G) (H) and (I), Over Limit Sites (OLSs, red dots) were grouped into 4 classes: 1-3, 3-5, 5-10, and $>10$ according to the multiples of the limit value (Lead: $80 \mathrm{mg} / \mathrm{kg}$ )

2.3. Distribution of zinc (Zn), arsenic (As), copper $(\mathrm{Cu})$, and chromium $(\mathrm{Cr})$ in soils

According to ZHANG ET AL. (2016a), zinc (Zn), copper $(\mathrm{Cu})$, and chromium $(\mathrm{Cr})$ concentrations were attributable to the soil's parent rocks, and were also reflected by the spatial distribution of mineral surface structures, such as carbonates, organic matter, or clay. On the other hand, the high concentrations of lead $(\mathrm{Pb})$, cadmium (Cd), and copper $(\mathrm{Cu})$ in the topsoil of agricultural lands were mostly due to human activities. While $\mathrm{Zn}, \mathrm{As}, \mathrm{Cu}$, and $\mathrm{Cr}$ are scattered across the lands of China, they are not as densely distributed as cadmium or lead. According to Fig. 3, the occurrence of zinc, arsenic, copper, and chromium OLSs is relatively rare. 

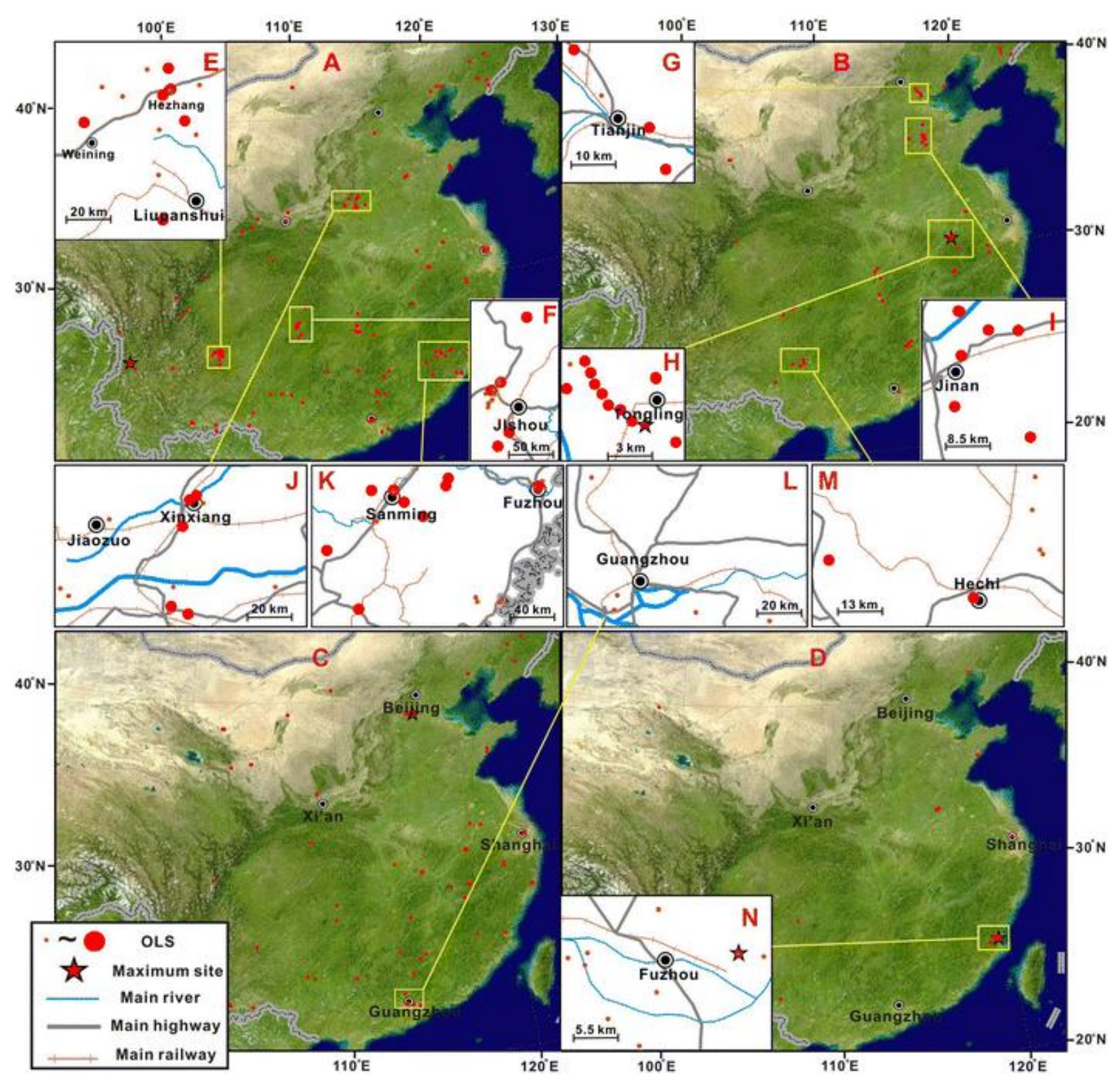

Fig. 3. Distribution of zinc (Figs A, E, F, J, K), arsenic (Figs B, G, H, I, M), copper (Figs C, L) and chromium (Figs D, N) OLSs across the country (Source: Duan et al., 2016)

Note: In (E) (F) (G) (H) (I) (J) (K) (L) (M) and (N), OLSs (red dots) were grouped into four classes: 1-3, 3-5, 5-10, and >10 according to the multiples of the limit values (Zn: $300 \mathrm{mg} / \mathrm{kg}$, As: $45 \mathrm{mg} / \mathrm{kg}$, Copper: $200 \mathrm{mg} / \mathrm{kg}$ and Cr: $350 \mathrm{mg} / \mathrm{kg}$ )

Of the 1789 sites sampled for zinc (Zn), the vast majority of the 199 zinc OLSs were located in southern China (Fig. 3A). Many of the Zn OLSs are situated in the Yangtze River watershed, from Guizhou Province to Shanghai, forming a cluster in Hezhang and Weining counties (Guizhou Province) (Fig. 3E) and Jishou (Hunan Province) (Fig. 3F). In southern China, there are several Zn OLSs in the province of Fujian, especially in the cities of Sanming and Nanping (Fig. 3K), which are close to $\mathrm{Pb}$ and $\mathrm{Zn}$ mines and smelters. The situation of Xinxiang (Henan Province) (Fig. 3J) is similar in this respect. The highest distribution of Zn OLSs was observed in Lanping County in Yunnan Province, with a $\mathrm{Zn}$ concentration of $49,210 \mathrm{mg} / \mathrm{kg}$, which is 164 times as high as the standard $\mathrm{Zn}$ threshold limit value (DUAN ET AL., 2016).

High arsenic (As) content in the soil is primarily attributable to arsenic-contaminated groundwater. Of the 1339 sites included in the research, 70 arsenic OLSs were identified, primarily distributed in the north China Plain, especially in Tianjin Municipality and Jinan City (Shandong Province), with some others scattered across southern China. The largest As OLS is located in the city of Tongling along the bank of the Yangtze River (Fig. 3H), with a 
concentration of $2300 \mathrm{mg} / \mathrm{kg}$, which is 51 times as high as the standard maximum value of $45 \mathrm{mg} / \mathrm{kg}$. In the region of the Pearl River basin, As OLSs were found around Hechi City (Guangxi Province) (Fig. 3M) (DUAN ET AL., 2016).

Of the 1997 copper (Cu) sampling sites, 101 $\mathrm{Cu}$ OLSs have been identified. The majority of copper OLSs were located on the south-eastern coast (Fig. 3C), forming a cluster in Guangzhou City (Fig. 3L). However, the largest copper OLS was found in Baoding City (Hebei Province), where the densest $\mathrm{Cu}$ concentration was $33,010 \mathrm{mg} / \mathrm{kg}$, 165 times as high as the standard maximum value of $200 \mathrm{mg} / \mathrm{kg}$ (DUAN ET AL., 2016).

Chromium (Cr) is viewed as a serious environmental pollutant, and is emitted by the steel, leather, and textile industries, among others (ZHANG ET AL., 2016b). Luckily, Cr OLSs are rare (Fig. 3D). The highest Cr OLS is located near Fuzhou (Fujian Province) (Fig. 3N), with a $\mathrm{Cr}$ concentration reaching $875.59 \mathrm{mg} / \mathrm{kg}$, about 2.5 times as high as the standard maximum value of $350 \mathrm{mg} / \mathrm{kg}$. ZHANG ET AL. (2016b) estimated the risk that $\mathrm{Cr}$ in arable soil poses on food safety in China, and concluded that agricultural practices should be suspended on $0.13 \%$ of the arable land in the country due to their heavy $\mathrm{Cr}$ contamination, while $1.26 \%$ of the soil faces a high risk of $\mathrm{Cr}$ pollution (DUAN ET AL., 2016).

\section{Soil pollution from agricultural activities}

The rapid economic growth and urbanization over the last thirty years have brought about substantial changes in the diet of China's population. In particular, there has been a shift from the grain-centered diet towards a more diverse diet: the significant increase in incomes has created a demand for more animal protein, and highquality vegetables and fruits. Between 1980 and 2002, the contribution of cereals and starchy roots to the average daily per capita calorie intake decreased by $17.4 \%$ and $13.5 \%$, respectively. On the other hand, during the same period, the contribution of vegetables and fruits to people's diet increased by $260 \%$ and $500 \%$, respectively (CHEN, 2007).

Accordingly, soils previously used for cultivating crops like grains and starchy roots have been gradually transformed into lands for more highvalue crops. Over the period of 1978-2014, the total land area used for cultivating grain crops dropped from 120.6 million ha to 112.7 million ha, while the land area used for oil-bearing crops increased from 6.2 to 14 million ha, that for vegetables increased from 3.3 to 21.4 million ha, and that for orchards increased from 1.6 to 13.1 million ha (an increase by 2.3 times, 6.5 times, and 8.2 times, respectively) (Fig. 4) (CHEN, 2007; NBSC, 2015).

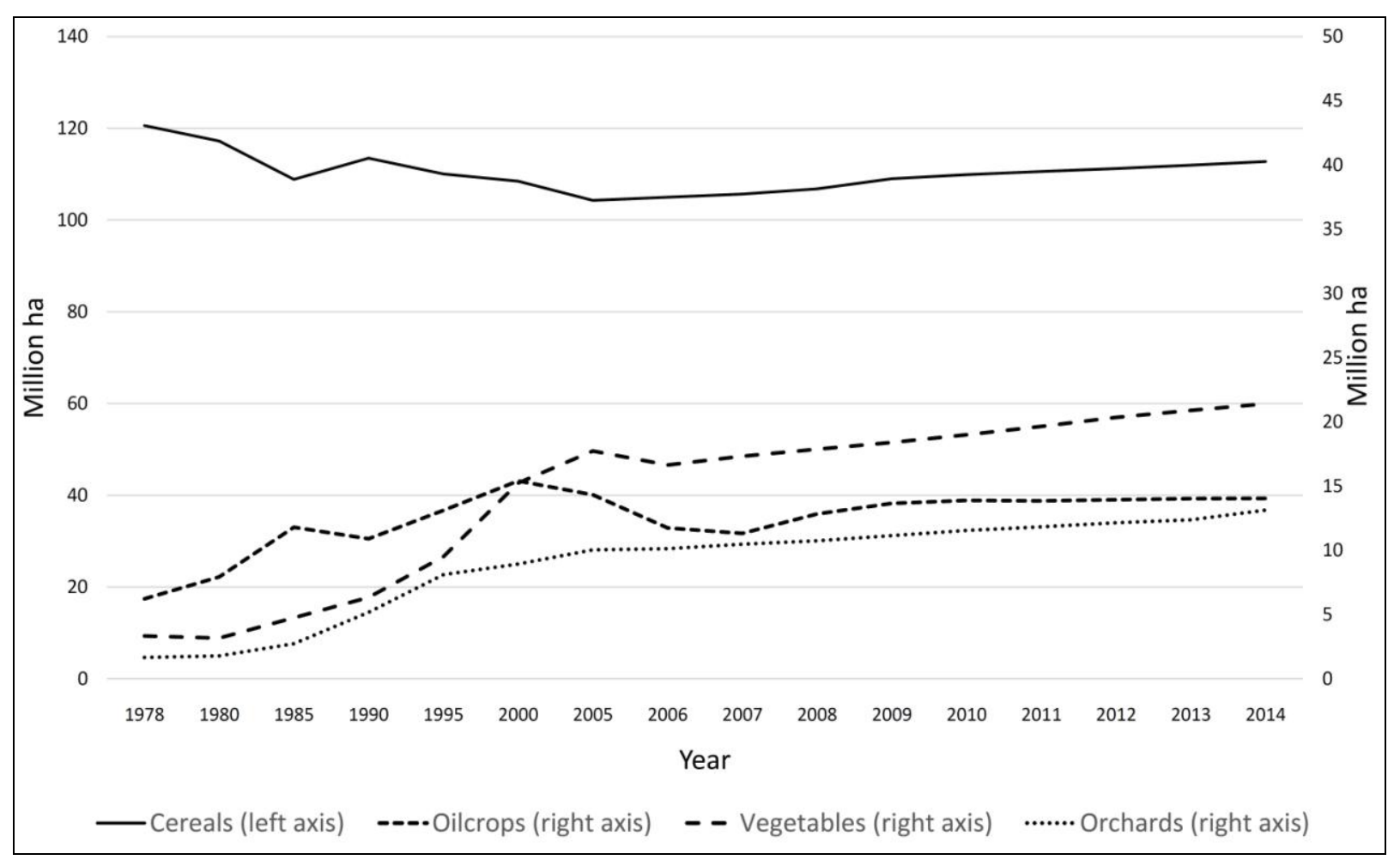

Fig. 4. Change of land areas for different types of agricultural production (1978-2014)(Source: NBSC, 2015) 
Changes in food consumption habits and a market-oriented approach to agriculture in China have called forth the structural reorganization of the country's agricultural system. Modifications in crop composition and crop yields fundamentally affect the way lands are utilized and managed, thereby also changing the capacity and nutrient cycles of soils. Different crop compositions require different nutrient supplies, as well as a specific balance of plant minerals applied to the soil, which also changes the physical and chemical properties of the soil. For example, the nutrient uptake of fruits and vegetables is significantly higher than that of cereal crops. Because vegetables have relatively underdeveloped root systems and an intensive growth and biomass accumulation period, they need a quicker soil nutrient release than cereals. On the other hand, oil-bearing crops need an ample supply of potassium (soybean kernels contain about 5 times more potassium than cereal crops).

These are some of the reasons underlying the high and growing levels of soil pollution generated by agricultural production. They lead, in particular, to the application of a growing amounts of fertilisers and pesticides, the production of additional amounts of animal excretion, and the use of wastewater for irrigation (DELANG, 2017). These issues are now discussed in turn.

\subsection{Soil pollution by wastewater irrigation}

Water sources in China are highly uneven, which results in an imbalanced water availability for irrigation. According to LU ET AL. (2015), the Yangtze and Pearl River basins, and the southeast and south-west river basins, produce only $40 \%$ of the total national grain yield, while over $70 \%$ of the water resources can be found in these regions. On the other hand, about $50 \%$ of the grain produced in China comes from the Songhua, Liaohe, and Haihe River basins in northern China, which only have $20 \%$ of the water resources (China Water Risk, 2016). Fig. 5 shows the mismatch between water resources and farmland in China's main agricultural provinces. The area with the greatest water scarcity in China is the north China Plain, which has $33.8 \%$ of the national cropland, but only $3.85 \%$ of the country's water resources (DELANG, 2016b).

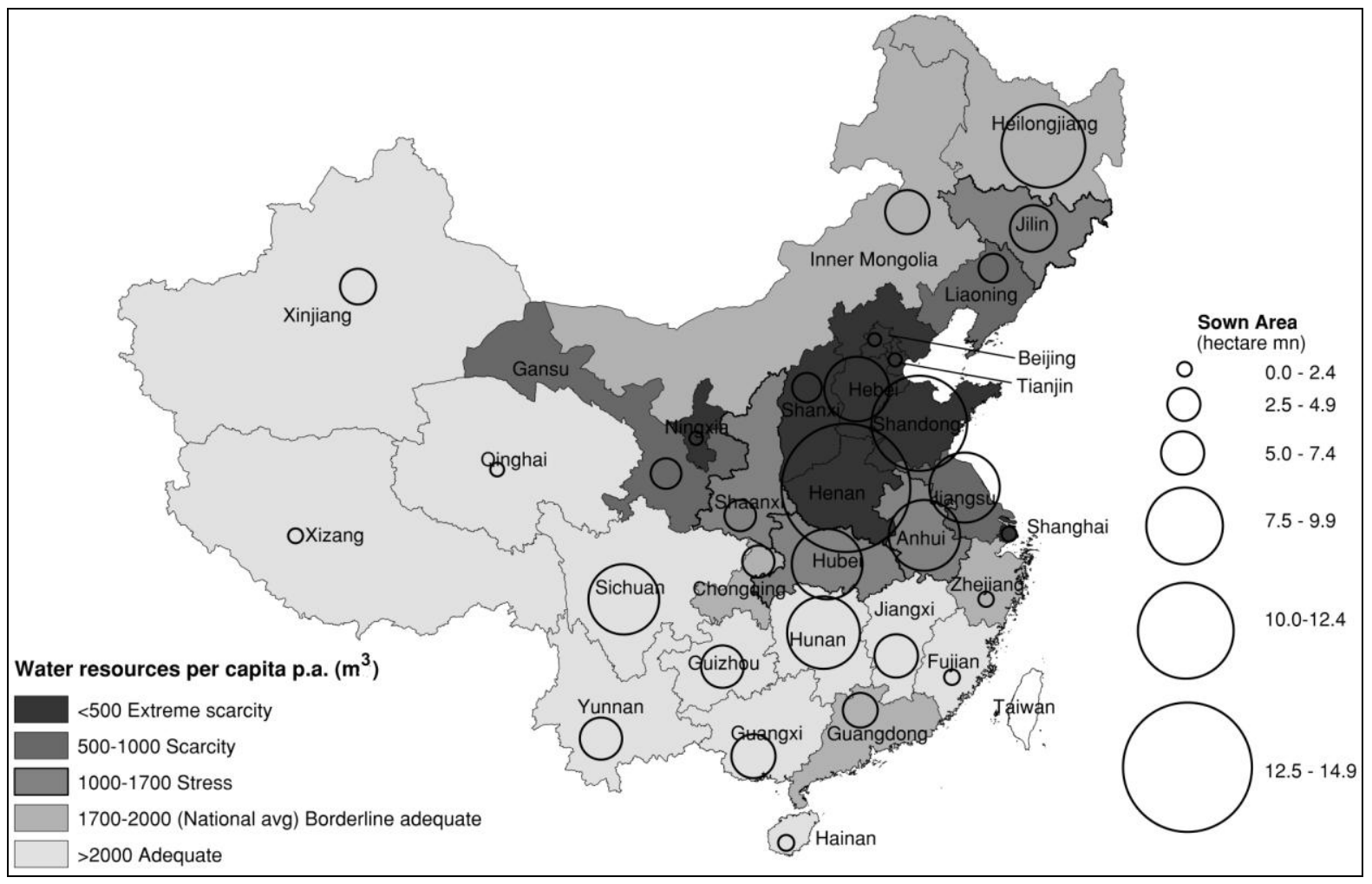

Fig. 5. China's 2012 sown area mapped onto water resources (Source: Tan, 2014)

The water scarcity in semi-arid and arid regions encourages water recycling. Since the 1950s, farmers have had to use urban and industrial wastewater (including sewage) to water their farmland, orchards, and vegetable gardens (CHEN,
2007). Wastewater and sewage sludge is rich in nutrients such as nitrogen, phosphorus, and potassium, therefore it can effectively improve the nutrient content of the soil to support crop growth (BAO ET AL., 2014). However, the use of 
untreated wastewater and sewage for irrigation can also increase the metal content in the soil and crops (including $\mathrm{Cd}, \mathrm{Pb}, \mathrm{Cu}$, and $\mathrm{Zn}$ ) (CHENG, 2003).

In China, approximately one third of the industrial effluent, and over $90 \%$ of the domestic sewage, is discharged untreated into rivers and lakes. Nearly $80 \%$ of China's cities (278 of them) have no wastewater treatment plants, and only a few of them plan to build one. A national survey revealed that in 1995, 3.62 million ha (about 1.6 times the affected area in the early 1980s) was irrigated by polluted water and sewage. This corresponded to $7.3 \%$ of China's total irrigated area, or $10 \%$ of the total land area irrigated with surface water. The area of lands directly irrigated with untreated urban sewage and industrial wastewater totaled 0.51 million ha (CHEN, 2007). In general, surface water contamination affects northern China more seriously than southern China, particularly the regions of the Haihe River, Yellow River, and Huaihe River basins (LU ET AL., 2015). On the other hand, about $40 \%$ of China's agricultural land was irrigated with groundwater, of which $90 \%$ was polluted, $60 \%$ of it seriously (QIU, 2010; WEE \& JOURDAN, 2013).

Tests showed that many crops are contaminated with heavy metals. As long as farmers continue to use untreated wastewater for irrigation, the contamination of the soils will continue, which will continue to damage crop quality and pose a direct threat to human health. In 2013, the government promulgated the "Arrangement for soil environment protection and comprehensive treatment work" to prohibit the practice of using wastewater contaminated with heavy metals or persistent organic pollutants for irrigation (LU ET AL., 2015). However, enforcing this rule is difficult, especially in northern China, due to the lack of good quality water. The authorities support farmers' efforts to drill deeper wells for irrigation, but this is only a temporary solution, while the original problem of polluting the rivers persists (CHINA WATER RISK, 2014). LU ET AL. (2015) argues that the government devotes little attention to the potential long-term effects of wastewater irrigation, and the resulting food safety issues. Since the public is not fully aware of the low quality of food stuffs, there are fewer pressures on the government to address the issue.

\subsection{Soil pollution by overuse of fertilizers}

Even though the overuse of fertilizers leads to soil contamination and food safety issues, agriculture in China largely relies on the use of chemical fertilizers (YANG, 2012). YANG \& FANG (2015)'s survey in five counties in east-central China to examine farmers' fertilizer application practices showed that $74 \%$ of the farmers in Shandong Province and $47 \%$ of the farmers in Shanxi Province have explained their increasing use of synthetic fertilizers with the decreasing use of organic fertilizers, and having to offset the decline in soil fertility. Furthermore, to keep inflation in check, the government has been imposing profit caps on farmers. As a result, many farmers have been struggling to make a living, which forces them to increase their crop yields through greater use of synthetic fertilizers.

As depicted in Fig. 6, the country's use of synthetic fertilizers has been steadily growing since the early 1960s, to meet the food demand of a huge population with a comparatively small agricultural area. According to China's Vice Minister of Agriculture, Zhang Taolin, chemical fertilizer use has increased by $5.2 \%$ a year over the last three decades (PATTON, 2015). By 2008, the country's total fertilizer consumption amounted to 52 million tons, which is more than one-third of the global consumption of fertilizers. Despite these efforts, the growth rate of agricultural output has been slowing down since the 1990s (SUN ET AL., 2012).

Nitrogen $(\mathrm{N})$, phosphate $(\mathrm{P})$, and potassium $(\mathrm{K})$ fertilizers are the three main chemical fertilizers used in China. According to LIU (2014), they are often applied in the proportion of 1:0.5:0.5, and internationally recognized limit for their maximum safe usage is between $225 \mathrm{~kg}$ per ha (CCICED, 2006) and $250 \mathrm{~kg}$ per ha (LIU, 2014). In China the amount applied is much larger: in 2011-2012 over $400 \mathrm{~kg}$ of fertilizers were applied per ha according to CHEN (2014), $480 \mathrm{~kg}$ per ha according to LIU (2014), $516 \mathrm{~kg}$ per ha according to LU ET AL. (2015), and $647.6 \mathrm{~kg}$ per ha according to the World Bank (PATTON, 2015). Not all provinces apply the same amount of fertilizers. According to LIU (2014) the south-eastern part of China has significantly higher fertilizer application rates than the northwestern part of the country. Fertilization rates in Fujian, Guangdong, Henan, Hubei, and Jiangsu exceed $690 \mathrm{~kg} \mathrm{ha}^{-1}$. The highest fertilization rate, about $908.7 \mathrm{~kg} \mathrm{ha}^{-1}$, was found in Fujian.

Nitrogen fertilizers are by far the most common (Fig. 6), and China has become the world's largest producer and consumer of synthetic $\mathrm{N}$ fertilizer (SMIL, 2013). The national average annual amount of nitrogen fertilizer use reached $230 \mathrm{~kg} \mathrm{~N} \mathrm{ha}^{-1}$ in croplands, which is the third largest in the world after Korea and Japan. Data from the Soil and Fertilizer Institute of the Chinese Academy of Agricultural Sciences (CAAS) reveal that the average levels of $\mathrm{N}$ fertilizer consumption exceed the internationally set threshold in half of the Chinese regions (YANG, 2012). In some provinces, the average 
$\mathrm{N}$ fertilizer use exceeds $400 \mathrm{~kg}^{-1} \mathrm{ha}^{-1}$ (in Guangdong Province it is of $448.5 \mathrm{~kg} \mathrm{ha}^{-1}$, Fig. 7), and in some counties with vegetable farms it is over $1000 \mathrm{~kg}$ ha $^{-1}$ (SUN ET AL., 2012). The highest application rates of phosphate fertilizer, about $259.8 \mathrm{~kg} \mathrm{ha}^{-1}$, were found in Henan, while the highest application rates of potassium fertilizer, about $264.73 \mathrm{~kg} \mathrm{ha}^{-1}$, were found in Fujian (LIU, 2014).

Besides fertilizer overuse, there is also misuse. Since the 1980s, the effectivity rate of fertilizer application has been decreasing. According to Yang, "only about $30 \%$ of the fertilizers China uses actually does any good, much lower than the $40 \%$ rates in western nations". A survey carried out by the agricultural authorities in Henan Province found that "only one-third of the three million tons of fertilizer used in the province was actually absorbed by crops" (YANG, 2012). A nationwide survey of pollution sources in 2007 showed that the total nitrogen loss from cropland was about 1.6 million tons, of which some 320,000 tons was from surface runoff and over 200,000 tons from underground leaching. The total phosphorus loss was of about 108,000 tons (SUN ET AL., 2012).

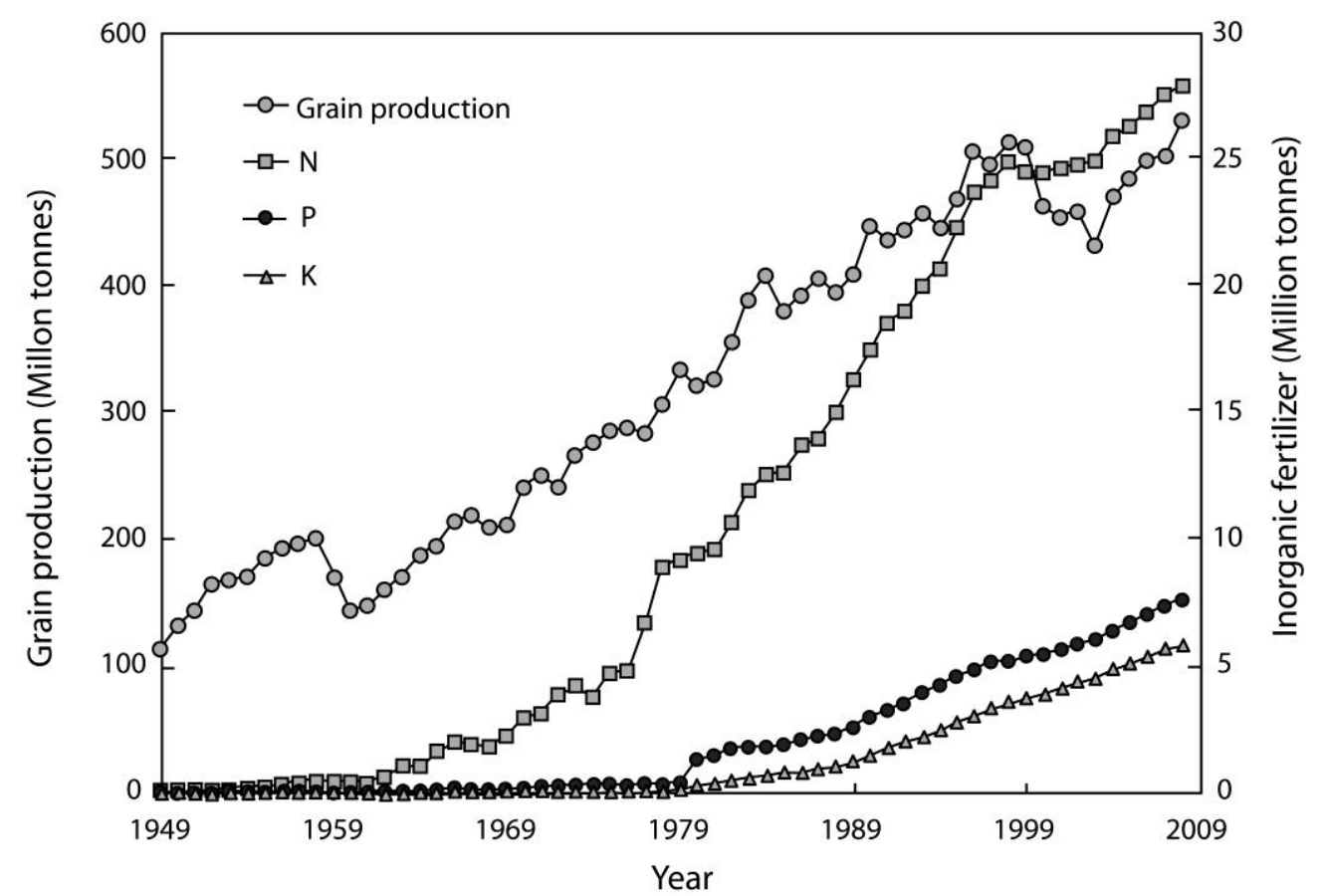

Fig. 6. Crop production and synthetic fertilizer consumption in China (1949-2008)(Source: Sun et al., 2012) $\mathrm{N}$ - nitrogen, $\mathrm{P}$ - phosphate, $\mathrm{K}$ - potassium

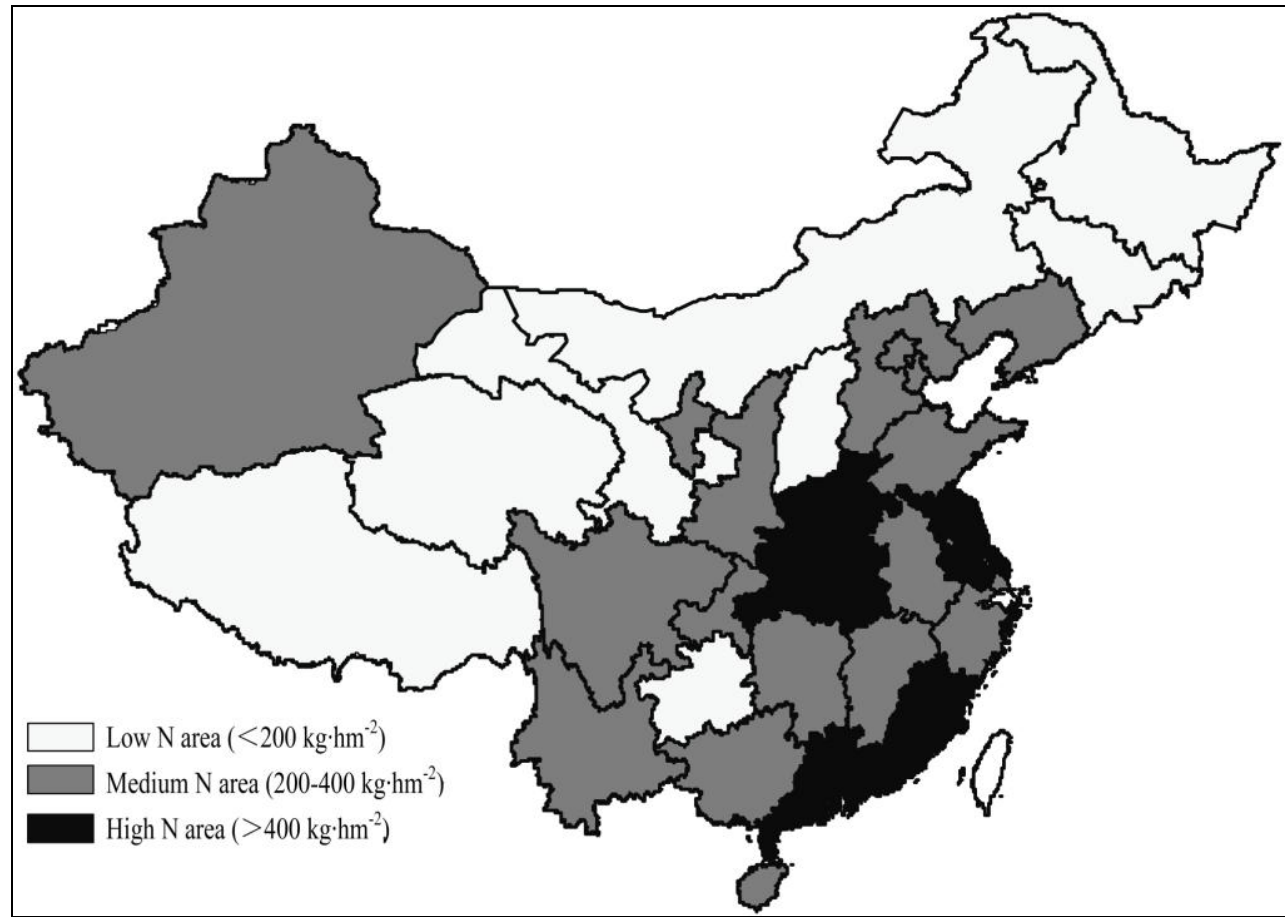

Fig. 7. Provincial differences in $\mathrm{N}$ fertilizer use intensity (Source: Liu, 2014) 


\subsection{Soil pollution by waste from livestock}

Intensive animal farming has spread rapidly across China over the last decades (Fig. 8), resulting in the production of substantial amounts of waste (SUN ET AL., 2012). Chinese farmers used to recycle and compost organic materials, such as animal waste, to guarantee high concentrations of organic matter and mineral nutrients in the soil. However, due to the rising costs of labor and rapid economic growth and urbanization, the recycling rate of organic matter has significantly dropped over the last decades, particularly in the more developed provinces of east and south-east China.

In 2007, the $\mathrm{N}$ and $\mathrm{P}$ discharge from human and livestock excretion exceeded the amount of synthetic fertilizers, and has become the primary source of non-point source (NPS) pollution in China. In 2007, livestock and poultry farming generated 243 million tons of waste, and 163 million tons of urine; the amount of $\mathrm{N}$ and $\mathrm{P}$ discharged from animal excretion totaled $1,024,800$ and 160,400 tons, respectively. Unfortunately, the majority of livestock

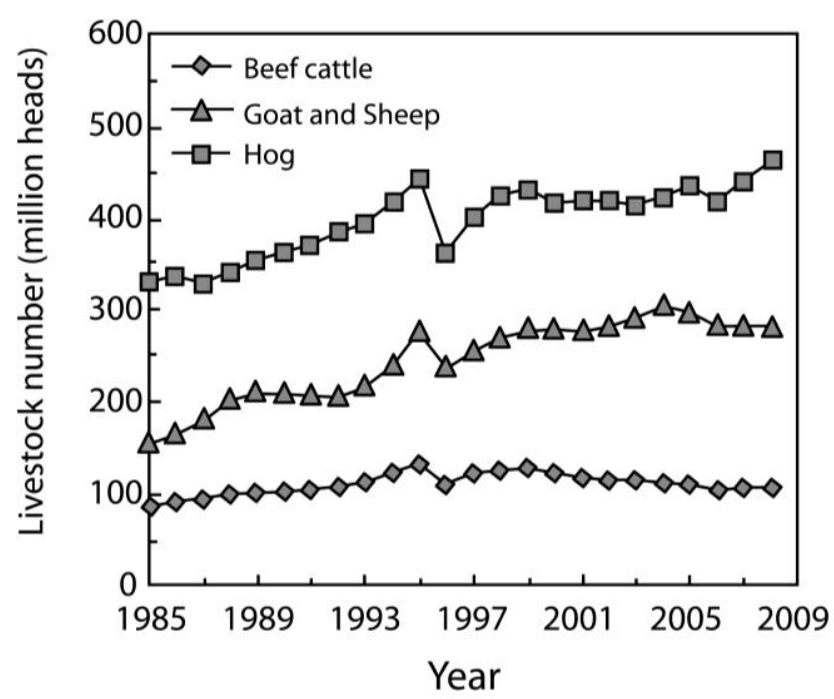

are kept by small farmers who ignore waste discharge regulations: $90 \%$ of animal farms in China have no or inadequate waste disposal or treatment plants. Ignoring the guidelines for the safe handling and storage of waste causes serious contamination (JU ET AL., 2005).

Organic manure makes up only $35 \%$ of the total amount of fertilizers applied to the land (JU ET AL., 2005). However, organic fertilizers are not safe either. Huang Hongxiang, a researcher at CAAS's Institute of Agricultural Resources and Regional Planning, points out that even though chemical fertilizers pollute the land and the environment, lower the quality of the soil, and affect the taste of crops, they are not toxic themselves. According to the researcher, organic fertilizers derived from animal excrements are the real cause for concern. The reason behind this is that in the past, chickens and pigs used to be grain-fed, whereas now "pig fodder might contain antibiotics and hormones, while chicken fodder can contain a range of chemicals" that can pollute the soil when their manure is used to fertilize crops (YANG, 2012).

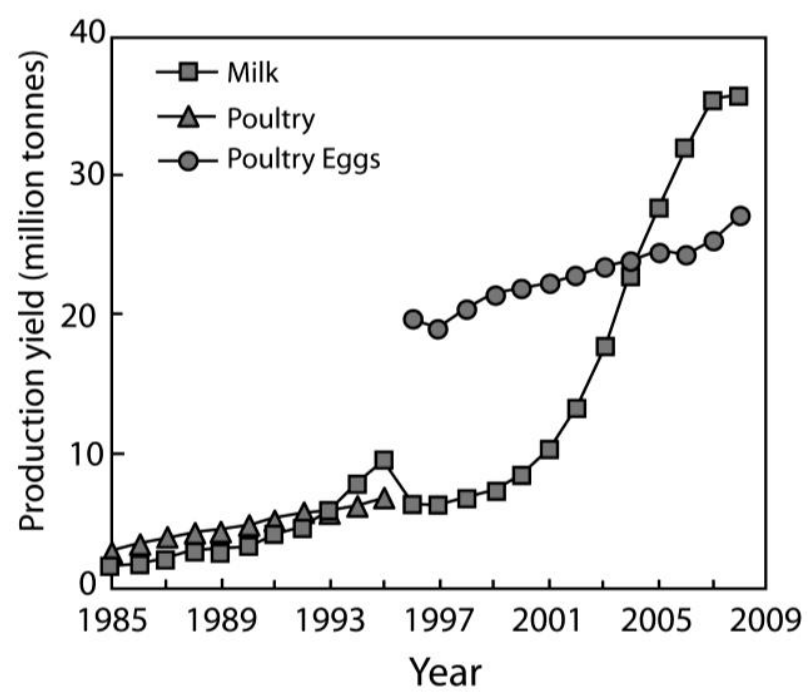

Fig. 8. Livestock numbers and milk and poultry production (1996-2008)(Source: Sun et al., 2012)

\subsection{Increasing use of pesticides}

For over 10 years, China has been the largest buyer of pesticides in the world, with the average amount of pesticides applied per unit area being double the global average (SUN ET AL., 2012). In 2000, organochlorine and organophosphorus pesticides made up over $39.4 \%$ and $37.0 \%$ of the total pesticide use, respectively, and the highly toxic organophosphorus and aminoformin pesticides made up $67.0 \%$ of the total amount of insecticides used. These pesticides are primarily sprayed on vegetables, fruit bearing trees, and cereal crops (rice and wheat). The utilization of pesticides has significantly boosted China's agricultural productivity (LU ET AL., 2015). According to ZHANG ET AL. (2011), during the growing process, $78 \%$ of fruits, $54 \%$ of vegetables, and $32 \%$ of cereals would be lost without the use of pesticides. Overall, the use of pesticides in China has prevented the loss of 89.44 million tons of cereals, 1.65 million tons of cotton, 2.53 million tons of oilseeds, and 78 million tons of vegetables.

However, pesticides are also highly toxic, and beyond a certain amount, they no longer help to boost agricultural output. Instead, they end up in the soil and water in amounts that exceed the ability of the natural environment to absorb, dilute and decompose them. According to ZHANG ET AL. (2011), 
only about $1 \%$ of these toxic substances does any good, while the other $99 \%$ will reach non-target soils and contaminate the water bodies and the atmosphere to eventually get absorbed by other living organism.

According to CHINA WATER RISK (2014), aware of the problems caused by excessive use of fertilizers, pesticides, and wastewater for irrigation, farmers sell their contaminated crops in the market and buy their own food, or reserve a portion of land for their own personal use, on which they do not apply these chemicals.

\section{Soil pollution from industrial activities}

The extensive mining and smelting with poor environmental standards over the last decades has resulted in large amounts of heavy metal contaminants affecting farmlands through atmospheric deposition, waste transportation, and irrigation with wastewater and sludge. This problem has been particularly important in southern China, which contains large mineral deposits (LU ET AL., 2015).

\subsection{Soil pollution from coal mining}

Coal is the most abundant energy resource in China. China's 12th Five-Year Plan (2011-2015) proposed the construction of 16 large coal power stations to meet the country's huge demand for energy. Unfortunately, coal power production is a water-intensive operation, and most coal mines are found in the drier areas in the north of the country (Fig. 9). The coal reserves in the dryland areas in Inner Mongolia AR, Ningxia AR, and Shaanxi Province are estimated to amount to 250 billion tons. The coal reserve of Xinjiang AR comprises 35\% of the total coal reserves of the country. In these areas, coal competes with agriculture for water. Fig. 9 shows the distribution of coal mines in China and the local precipitation. Inner Mongolia, which is China's largest coal-producing area, possesses 26\% of China's coal reserves, but only $1.6 \%$ of its water (GREENPEACE, 2012).

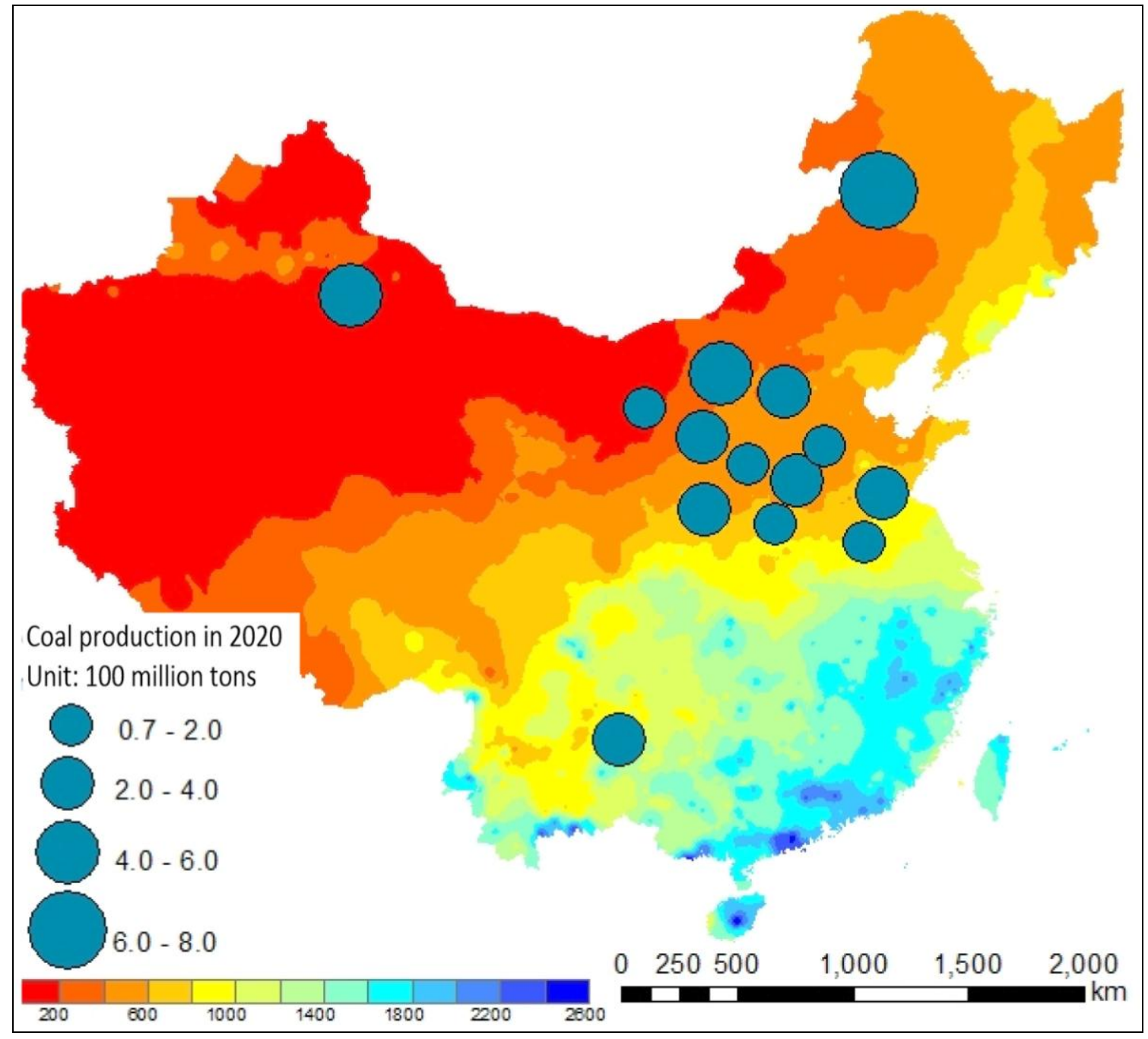

Fig. 9. Major coal mining bases under the 12th Five-Year Plan (color indicates annual precipitation, mm/a) (Source: Greenpeace, 2012) 
The exploitation of coal supplies brings serious ecological problems (LADA, 2010). Surface mining (also known as open cast, mountaintop, or strip mining) involves removing the top layers of the soil and rocks to dig the coal closer to the surface. In many cases, "mountains may be blasted apart to reach thin coal seams within, leaving permanent scars on the landscape as a result" (GREENPEACE, 2016). According to Greenpeace, surface mining devastates landscapes, woodlands, and wildlife habitats when the vegetation and topsoil are destroyed and cleared. This destructive practice results in soil erosion and the ruination of arable land. Although coal companies need to submit sound mine reclamation plans before starting their mining activities, the rehabilitation of water supplies, ecosystems, and air quality is a long and difficult process. In particular, re-seeding the native vegetation is challenging due to the extensive damage inflicted on the soil during the mining. Worse still, if a coal mining company goes bankrupt, the expensive mine reclamation process may not be completed. According to a 2004 estimate, coal mining in China devastated 3.2 million ha of land, but only $10-12 \%$ of the degraded land area was rehabilitated (SUN ET AL., 2012).

Underground coal mines can cause subsidence when a mine collapse occurs and the surface land starts to shift downwards. On average, 0.2 ha of land sinks per 10,000 t of mined coal. Subsidence also results in massive amounts of soil and waste rock being exposed to the surface, some of which may be toxic and come into contact with soils (SUN ET AL., 2012).

About 73.5\% of Inner Mongolia's grasslands already suffers from land degradation, and open-pit coal mining has only worsened the desertification process. Deng Ping, a campaigner for Greenpeace China pointed out that "In order to dig out the coal, you need to pump out the water". During this process, the extracted water becomes contaminated. Coal mining "has destroyed huge areas of grassland and destroyed the water system" (ROBERTS, 2015). According to the Hulun Buir Grassland Supervision Station and the Inner Mongolia Grassland Survey and Design Institute, the areas affected by grassland degradation, desertification, and salinization in Inner Mongolia totaled 3.982 million ha at the beginning of this century, which means that the size of the affected area almost doubled since the 1980s, when it was 2.097 million ha (GREENPEACE, 2012).

Even when the negative environmental impacts from the extraction of coal are minimized, the burning of coal causes air pollution, which degrades the vegetation and the soil. CHEN (2007) argued that high coal burning rates made China have the highest levels of soot and $\mathrm{SO}_{2}$ emissions in the world. As a result, China has been affected by high acid deposition levels with $\mathrm{SO}_{2}$ being the main pollutant. An increasing number of site-specific field studies and leaching experiments suggest that acid rain contributes to soil degradation, particularly in the southern and south-eastern parts of China (DELANG, 2016a) (Fig. 10).

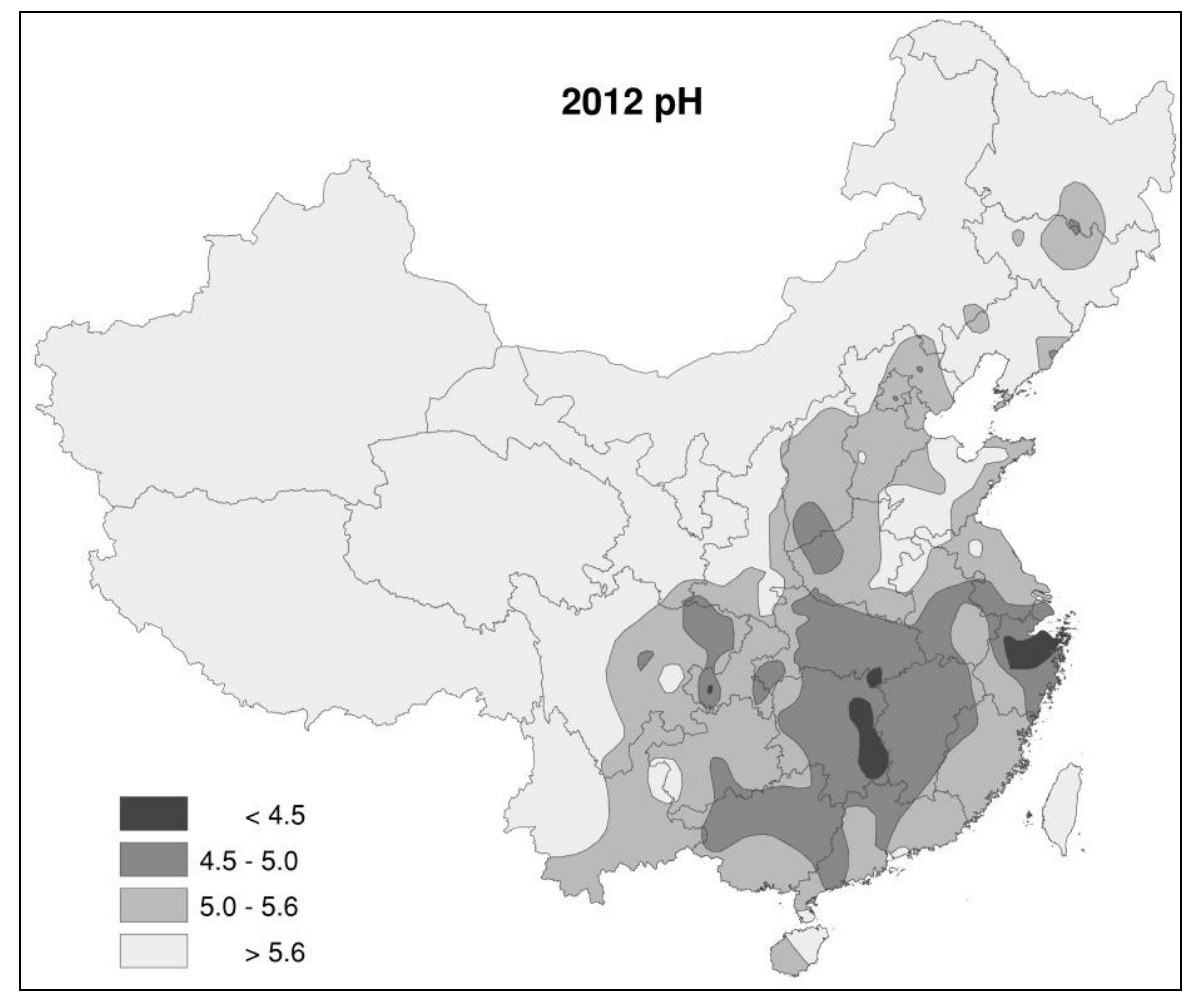

Fig. 10. Annual average pH values of precipitation in China in 2012 (Source: Tang \& Wu, 2012) 


\subsection{Pollution by industrial emission}

Industrial emissions are a significant source of air pollution. When the airborne toxic chemicals and heavy metals fall back to the ground, they pollute the soil. Industrial emissions are some of the major sources of heavy metal pollution in China. While the concentration of Cadmium (Cd) in the atmosphere is relatively low (usually below $1.0 \mathrm{pg} / \mathrm{L}$ ) in rural areas without industrial activities, industrial areas show significantly higher values, reaching up to $100 \mathrm{pg} / \mathrm{L}$. Soils in industrial areas can absorb Cd from the air and through precipitation. As a large agricultural country, China also produces large quantities of mercury $(\mathrm{Hg})$ emissions from biomass burning (HUANG ET AL., 2011). Biomass burning includes the outbreak of open fires (such as forest and grassland fires, and crop residue burning in fields) and biofuel combustion (such as crop residues and wood used as fuel).

Greenpeace has examined official statistics to conclude that the iron and steel industries are the largest contributors to cadmium and lead pollution in China, but there is also a considerable overlap between regions producing nonferrous metals and crop producing areas (GREENPEACE, 2014). Table 2 shows the top ten provinces producing nonferrous metals. Among them, Inner Mongolia, Shandong, Henan, Jiangxi, Hunan, and Xinjiang AR are also major grain crop producers (Fig. 5).

Table 2. Top ten nonferrous metal producing provinces in China in 2015 (Source: Cnal, 2016)

\begin{tabular}{|l|l|c|}
\hline No. & \multicolumn{1}{|c|}{ Province } & Output (tons) \\
\hline 1 & Shandong & $9,182,036$ \\
\hline 2 & Xinjiang & $6,014,419$ \\
\hline 3 & Henan & $5,213,468$ \\
\hline 4 & Gansu & $3,813,625$ \\
\hline 5 & Inner Mongolia & $3,403,519$ \\
\hline 6 & Yunnan & $3,328,341$ \\
\hline 7 & Hunan & $2,674,557$ \\
\hline 8 & Qinghai & $2,306,090$ \\
\hline 9 & Shannxi & $2,006,890$ \\
\hline 10 & Jiangxi & $1,677,993$ \\
\hline
\end{tabular}

\section{Soil pollution from urbanization}

Urbanization is one of the major social trends affecting the planet. China has a relatively low level of urbanization. However, being the country with the largest population, it is also home to the world's largest urban population (CHEN, 2007). Starting with the economic reform of 1978, China experienced a dramatic increase in urban population, from $17.9 \%$ to around $55 \%$ of its population by 2015 (STEINBOCK, 2010). The rapid urbanization along with the rapid economic growth over the last three decades, has exacerbated the problem of agricultural land scarcity and soil pollution in China.

First, urbanization withdraws the best land from cultivation. Cities have historically been formed near the most fertile lands. When the cities expand, the new buildings are built on that farmland. Urbanisation has contributed to the growth rate in agricultural output slowing down since the 1990s (Fig. 6).

Second, as pollution is concentrated, it cannot dilute to levels that are manageable by the natural environment. Soil pollution problems are much more severe in ecological deficit areas and in densely inhabited conurbations because of the concentration of pollutants. For example, crudely disposing of sewage and waste from a big city creates water or land pollution. However, the same number of people and the same volume of sewage might not create a problem if it were created in 10 smaller cities or 100 small towns. The same is true for acid deposition caused by the high concentration of pollutants emitted in cities.

China's ecological footprint (people's impact on the ecosystem) has been steadily increasing over the years, while the biocapacity (the capacity of the productive land to provide resources as well as to eliminate waste) has been gradually decreasing. In the 1960s, China's ecological footprint per capita was about 1 gha (global hectares, which represents the productive capacity of one hectare of available land, at global average biological productivity levels), about the same as its biocapacity (Fig. 11). At that time, China's economy could be said to have been sustainable. By 2012, China's ecological footprint per capita reached 3.38 gha, while its biocapacity had dropped to 0.94 gha, as a result of environmental degradation. In 2012 the per capita ecological footprint was 3.6 times higher than the available biocapacity (FOOTPRINTNETWORK, 2016). However, the situation is worse in its largest urban areas. In 2009, the per capita ecological footprint in Shanghai and Beijing was about 4 gha, which was 13 times larger than the local biocapacity. For comparison, during the same year, the biocapacity of Yunnan province exceeded its ecological footprint (WWF, 2014). 


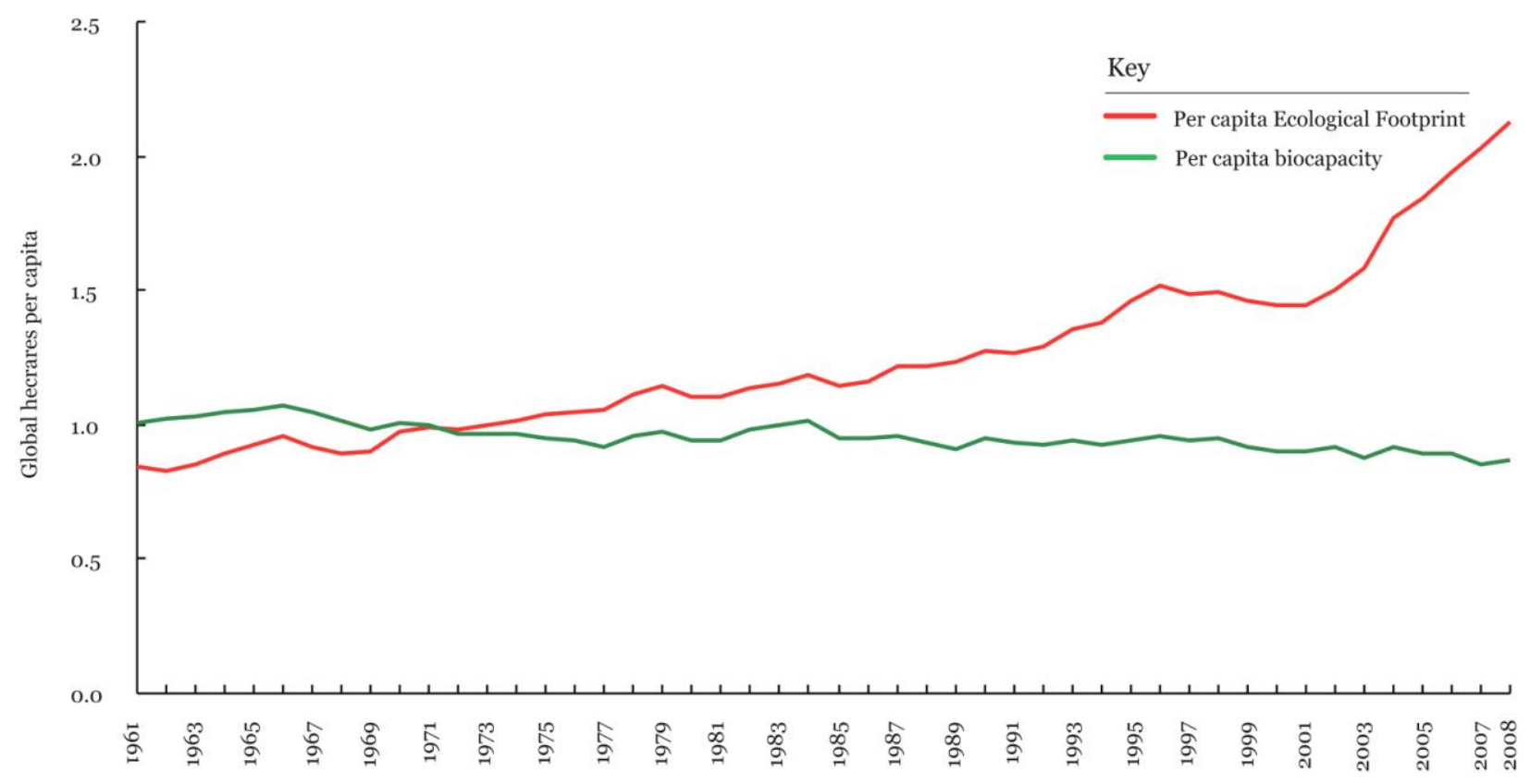

Fig. 11. China's per capita ecological footprint and biocapacity (1961-2008)(Source: Footprintnetwork, 2016)

The disposal of waste did not always lead to soil contamination. In past centuries, people primarily used natural materials (coming from plants, animals, or the minerals found in the soil), therefore the waste and by-products were mostly organic (carbon-based) and would gradually decompose. However, during the $20^{\text {th }}$ century, new types of synthetic materials, such as plastics and composites, have been invented, which the environment takes much longer to decompose. For instance, it can take up to 500 years for plastic to decompose. And while recycling simple items like newspapers or aluminum cans is relatively easy, it is much more challenging to do the same with more complex objects that are made from composite materials.

According to CHEN (2007), urban and industrial soil contamination is responsible for one-third to half of the total contaminated arable land area in the country, with a higher density in the rural- urban transition zones. Owing to the rapid industrialization and urbanization over the last thirty years, China's municipal solid waste (MSW) production has also increased significantly. FU ET AL. (2015) reported that the volume of MSW reached 180 million tons in 2010 and was projected to reach up to 210 million tons in 2015 (Fig. 12). ZHENG ET AL. (2014) provides comparable data of $1.12 \mathrm{~kg}$ MSW produced in China's cities, per capita in 2015; but ZHANG ET AL. (2015) suggests that this amount may be greater in large cities such as Beijing, Shanghai, and Guangzhou. In 2011, CBI CHINA (2011) predicted that the total amount would likely reach 323 million tons by 2020 , and 480 million tons by 2030 . Although the percentage of MSW that is treated has been steadily increasing, the amount of waste has also been growing, by 8 to $10 \%$ a year.

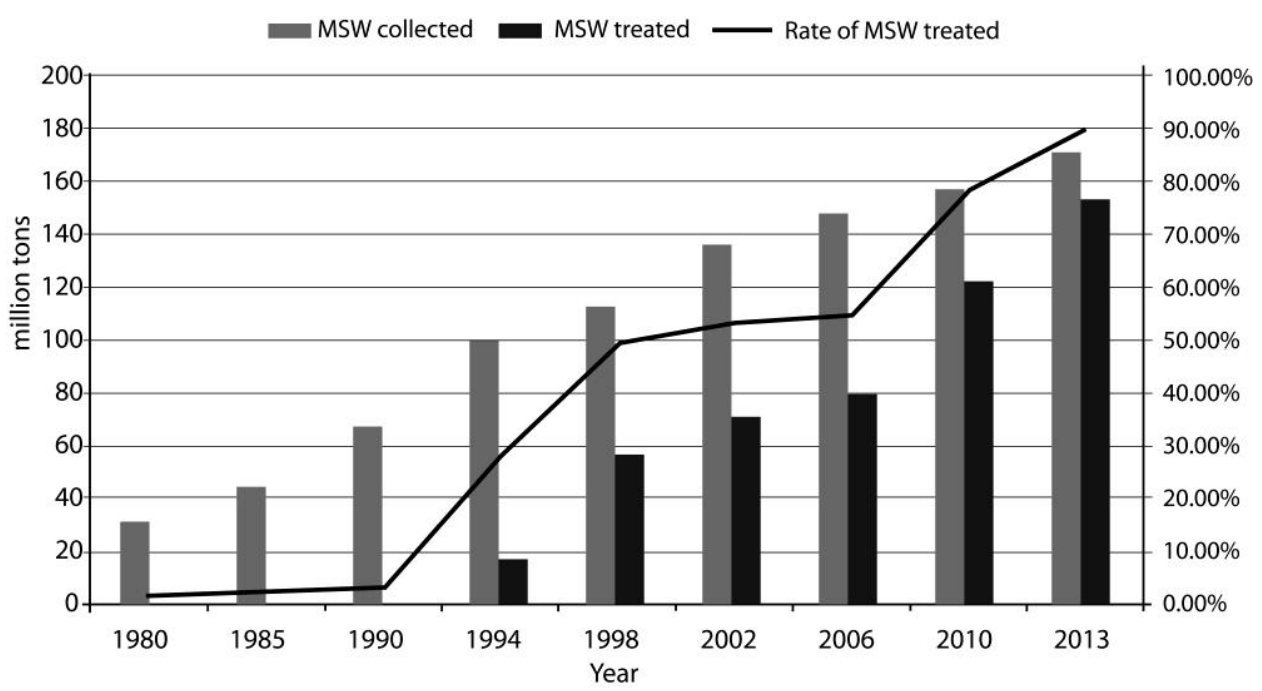

Fig. 12. Municipal solid waste (MSW) management in China (1980-2013)(Source: Zhang et al., 2015) 
While the total amount of municipal solid waste is increasing rapidly, the capacity of municipal solid waste management facilities is both limited and insufficient. It was estimated that accumulated amounts of untreated municipal solid waste had reached 7 billion tons in urban areas by 2000 . In 2013, 10\% of municipal solid waste was still left untreated (Fig. 12). In terms of the safe disposal rates in different regions, the safe disposal rates in coastal regions (Beijing, Shanghai, and the provinces of Tianjin, Shandong, Fujian, Jiangsu, Zhejiang) and western regions (Qinghai, Sichuan, Guizhou, Yunnan, and Shaanxi) are higher than in the central inland regions (Shanxi, Henan, Anhui, Hunan, and Hubei) (Fig. 13) (CHEN ET AL., 2010). Severe soil contamination not only occurs at and around garbage disposal sites, which occupy an estimated total area of over 55,000 ha in China, but also in the extensive rural-urban transition zones where municipal solid waste landfills are under little control (CHEN, 2007).

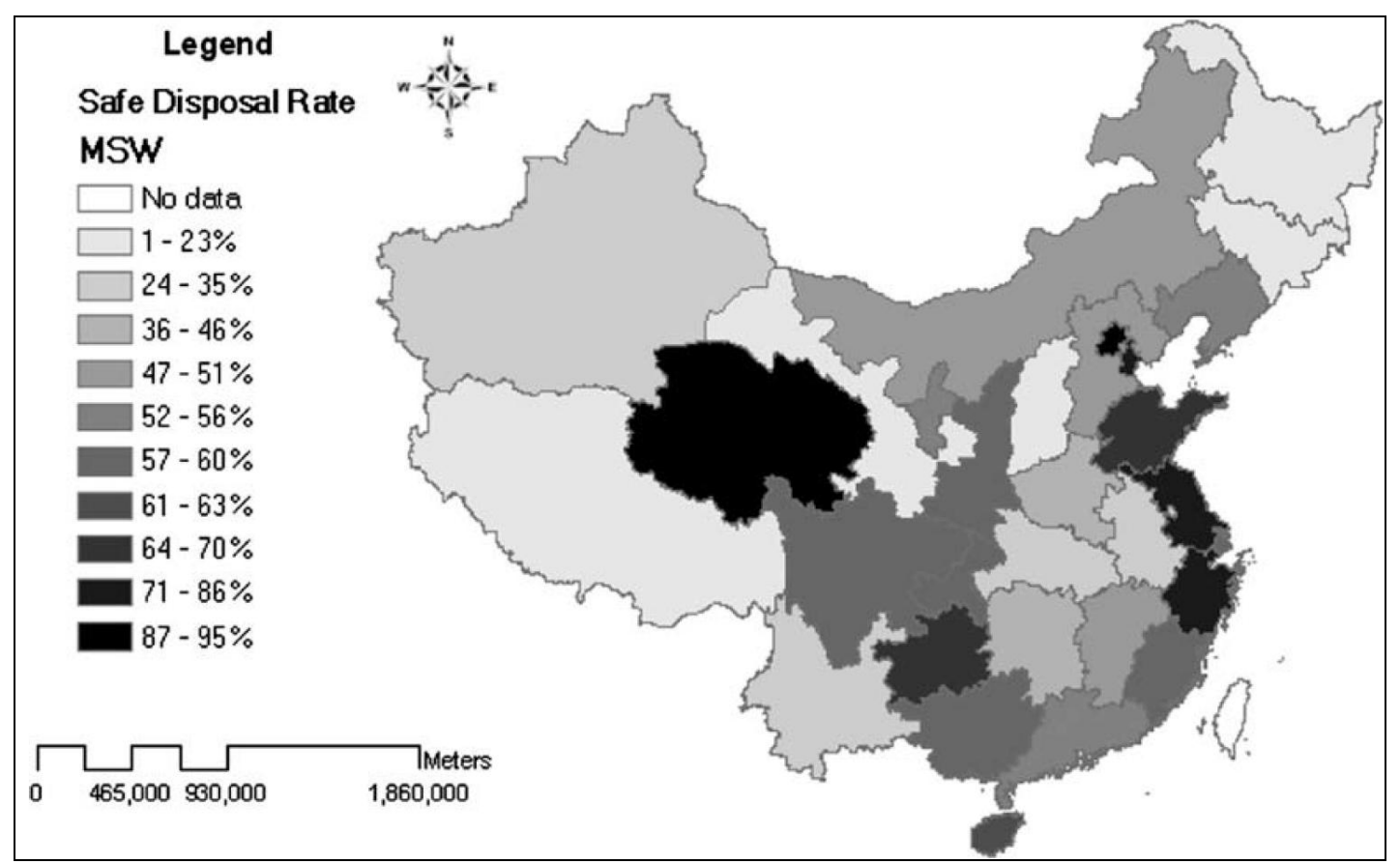

Fig. 13. Safe disposal rates of municipal solid waste (MSW) at the provincial level (2007) (Source: Chen et al., 2010)

\subsection{Road construction and vehicle pollution}

With the rapid development of the economy, automobiles have become more affordable. As a result, traffic-related pollution has developed into a significant contributor to urban environmental degradation and public health problems (LI ET AL., 2007). While road construction may lead to soil erosion, the traffic itself contributes to the accumulation of heavy metals. Many studies showed that traffic-related pollution can result in the accumulation of some heavy metals such as $\mathrm{Pb}$ (lead), Cd (cadmium), $\mathrm{Zn}$ (zinc), and $\mathrm{Cu}$ (copper) in both the soil and plants along roads, primarily attributable to vehicle emissions and the abrasion of roads (LI ET AL., 2007). Some roads and highways have a "belt" of contaminated land from trafficrelated pollution. Alongside these roads, damages to vegetation and the change of the surface soil layer structure causes land degradation (LADA, 2010). For example, Li et al.'s study in Lanzhou (Gansu Province) showed that soils along roads contained higher concentrations of $\mathrm{Zn}, \mathrm{Pb}, \mathrm{Cd}, \mathrm{Hg}$ (mercury), $\mathrm{Cr}$ (chromium), and $\mathrm{Cu}$ than park soils, with the concentration of $\mathrm{Hg}$ in roadside soils exceeding the levels of $\mathrm{Hg}$ in park soils by $71.4 \%$. LI concluded that traffic-related pollution is a significant contributor to urban soil degradation (LI ET AL., 2007).

Similarly, HAN ET AL. (2009) carried out an investigation on the $532 \mathrm{~km}$ long Shen-Ha Highway from Shenyang (Liaoning Province) to Harbin (Heilongjiang Province), where about 50,000 vehicles traveled daily. The results showed that vehicle emissions were one of the major sources of heavy metal pollution in the area. $\mathrm{Pb}$ was the major contaminant found in the soils in the area surrounding the Shen-Ha Highway, and the most polluted area was 20 to $40 \mathrm{~m}$ away from the highway, posing an immediate threat to the ecological environment, especially the cropland in the fields adjacent to roadsides (HAN ET AL., 2009; YAN ET AL., 2013). 


\section{Conclusion}

Concerns have been growing nationwide over the issues of soil degradation and the availability of arable land. In late 2013, a national soil survey published by China's Ministry of Land and Resources reported that the area of lands suitable for cop production was gradually decreasing due to soil degradation, pollution, and urbanization. The survey revealed that between 2006 and 2009, 0.2\% of China's arable land had become degraded due to these processes, and $2.5 \%$ of the land was declared unfit for farming due to the presence of heavy metals and other contaminants (HE, 2014c).

The state of soil erosion and soil pollution raise deep concerns in China, especially because China has little agricultural land per capita. Natural factors play an important role in the soil degradation process since many areas are prone to water erosion, wind erosion, and freeze-thaw erosion. On the other hand, soil pollution is mainly attributable to human activities. One of the constraints that have led to soil pollution is the problem of water scarcity. Farmers solve this problem by applying industrial wastewater and urban sewage, which pollutes the soil and has direct consequences on the quality of the food grown. In addition, farmers apply large amounts of fertilizers and pesticides, well beyond what is necessary to grow food and kill pests. This increases soil pollution, and gradually leads to soil degradation. From the perspective of farming, there is also the problem of pollution from livestock waste, which contains considerable amounts of antibiotics.

In addition to the detrimental practices of farmers, sources of soil pollution include the general processes of industrialization and urbanization, which indirectly result in soil pollution through the deposition of air pollutants. As this paper has hinted to, soil pollution is very difficult to address, because the causes of soil pollution are diverse, and are closely related to the production of food or the industrial activities that form the backbone of the Chinese economy. Addressing soil pollution involves reforming the economic activities that are the backbone of the Chinese economy. This can only be done at high economic costs, which in the present climate of a slowing economy is difficult to implement or justify. Nevertheless, China has finally officially acknowledged that there is a problem with its soils, and is starting to address it.

\section{References}

Bao Z., Wu W.Y., Liu H.L., Chen H.H., Yin S.Y. 2014. Impact of Long-Term Irrigation with Sewage on Heavy Metals in
Soils, Crops, and Groundwater - a Case Study in Beijing. Pol. J. Environ. Stud., 23, 2: 309-318.

CBI China. China Waste to Energy Outlook 2011. Updating Technology and Management, Powering Up the LowCarbon Economy. http://events.cbichina.com/con/wte2011/ index.html [Access 15.09.2017].

CCICED (China Council for International Cooperation on Environment and Development) 2006. Environmental Issues and Countermeasures Facing New Rural Development in China. Bejing: CCICED. http://www.china. com.cn/tech/2008-02/03/content_9642876.htm [Access 15.09.2017].

Chen J. 2007. Rapid urbanization in China: A real challenge to soil protection and food security. Catena, 69:1-15. DOI: 10.1016/j.catena.2006.04.019.

Chen N. 2014 (December). Chemical Fertilizer Overuse Linked to Land Degradation in China. http://english.cas.cn/ newsroom/china_research/201412/t20141226_133647.sh tml [Access 15.09.2017].

Chen X.D., Geng Y., Fujita T. 2010. An overview of municipal solid waste management in China. Waste Management, 30(4): 716-724. DOI:10.1016/j.wasman.2009.10.011

Cheng S. 2003. Heavy Metal Pollution in China: Origin, Pattern and Control. Environ. Sci. Pollut. Res., 10(3): 192-198.

China Water Risk 2014 (April). Crying Lands: China's Polluted Waterscape. http://chinawaterrisk.org/interviews/ cryinglands-chinas-polluted-waterscape/ [Access 15.09.2017].

China Water Risk 2016. Top 4 Farmers. http://chinawaterrisk. org/big-picture/top-4-farmers/ [Access 15.09.2017].

Cnal 2016 (March). Main nonferrous metal producing provinces in China in 2015. China nonferrous metals. [in Chinese]. https://news.cnal.com/2016/03-01/1456801860427801. shtml [Access 15.09.2017].

Delang C.0. 2016a. China's Air Pollution Problems. Routledge, London.

Delang C.O. 2016b. China's Water Pollution Problems. Routledge, London.

Delang C.0. 2017. China's Soil Pollution and Degradation Problems. Routledge, London.

Delang C.O., Yuan Z. 2015. China's Grain for Green Program. Springer, Heidelberg.

Duan Q.N., Lee J.C., Liu Y.S., Chen H., Hu H.Y. 2016. Distribution of Heavy Metal Pollution in Surface Soil Samples in China: A Graphical Review. Bull. Environ. Contamin. Tox., 97(3): 303-309. DOI: 10.1007/s00128- 016-1857-9.

Footprintnetwork. 2016. Public Data Package. http://www.footprintnetwork.org/en/index.php/GFN/p age/public_data_package [Access 15.09.2017].

Fu Z., Zhang S., Li X., Shao J., Wang K., Chen H. 2015. MSW oxy-enriched incineration technology applied in China: Combustion temperature, flue gas loss and economic considerations. Waste Management, 38: 149-156.

Greenpeace 2012 (August). Thirty Coal: A Water Crisis Exacerbated. http://www.greenpeace.org/eastasia/ publications/reports/climate-energy/2012/thirsty-coalwater-crisis/ [Access 15.11.2017].

Greenpeace 2014 (April). "Cadmium rice": heavy metal pollution of China's rice crops. http://www.greenpeace. org/eastasia/publications/reports/toxics/2014/cadmiu m-rice-heavy-metal/

Greenpeace 2016 (July). About coal mining impacts. http://www.greenpeace.org/international/en/campaign s/climate-change/coal/Mining-impacts/

Han D.C., Zhang X.K., Tomar V.V.S., Li Q., Wen D.Z., Liang W.J. 2009. Effects of heavy metal pollution of highway origin on soil nematode guilds in north Shenyang, China. J. Environ. Sci., 21: 193-198. DOI: 10.1016/S1001-0742(08)62250-0. 
He G. 2014a. Special report: the legacy of Hunan's polluted soils. China Dialogue. https://www.chinadialogue.net/ article/show/single/en/7076-Special-report-the-legacyof-Hunan-s-polluted-soils

He G. 2014b. Special report: The victims of China's soil pollution crisis. China Dialogue. https://www.chinadialogue. net/article/show/single/en/7073-Special-report-Thevictims-of-China-s-soil-pollution-crisis [Access 15.09.2017].

He G. 2014c. In China's Heartland, A Toxic Trail Leads from Factories to Fields to Food. http://e360.yale.edu/feature/ chinas_toxic_trail_leads_from_factories_to_food/2784/

Huang X., Li M.M., Friedli H.R., Song Y., Chang D., Zhu L. 2011. Mercury Emissions from Biomass Burning in China. Environ. Sci. Technol., 45: 9442-9448. http://pubs.acs.org/ doi/abs/10.1021/es202224e

Ju X.T., Zhang F.S., Bao X.M., Römheld V., Roelcke M. 2005. Utilization and management of organic wastes in Chinese agriculture: Past, present and perspectives. Science in China Series C: Life Sciences, 48, Suppl. 2: 965-979. DOI: 10.1007/BF03187135. http://link.springer.com/article/ $10.1007 / \mathrm{BF} 03187135$

LADA 2010 (October). China National Level Report of Land Degradation Assessment in Drylands. Prepared by: LADA Project Team, P.R. China. Rome: FAO.

Li F.R., Kang L.F., Gao X.Q., Hua W., Yang F.W., Hei W.L. 2007. Traffic-Related Heavy Metal Accumulation in Soils and Plants in Northwest China. Soil \& Sediment Contam., 16: 473-484. DOI: $10.1080 / 1532038070149168$

Li Y.X., Yu Y., Yang. Z.F., Shen Z.Y., Wang X., Cai Y.P. 2016. A comparison of metal distribution in surface dust and soil among super city, town, and rural area. Environ. Sci. Pollut. Res., 23: 7849-7860. DOI 10.1007/s11356-0155911-7.

Liu G.N., Wang J., Zhang E., Hou J., Liu X.H. 2016. Heavy metal speciation and risk assessment in dry land and paddy soils near mining areas at Southern China. Environ. Sci. Pollut. Res., 23: 8709-8720. DOI 10.1007/s11356-0166114-6.

Liu Q.P. 2014. Distribution of Fertilizer Application and Its Environmental Risk in Different Provinces of China Scientia Agricultura Sinica, 47(18): 3596-3605. DOI: 10.3864/j.issn.0578-1752.2014.18.008 [in Chinese].

Lu Y.L., Song S., Wang R.S., Liu Z.Y., Meng J., Sweetman A.J. et al. 2015. Impacts of Soil and Water Pollution on Food Safety and Health Risks in China. Environ. Int., 77: 5-15. http://dx.doi.org/10.1016/j.envint.2014.12.010

MEP 2014. The national soil pollution condition investigation communique. http://www.gov.cn/foot/site1/20140417/ 782bcb88840814ba158d01.pdf [in Chinese].

NBSC 2015. National Bureau of Statistics of China: Statistical Yearbooks 2015. Beijing: China Statistics Press. //www.stats.gov.cn/tjsj/ndsj/2015/indexch.htm [Access 15.09.2017].

Patton D. 2015. China farm pollution worsens, despite moves to curb excessive fertilisers, pesticides. Reuters. http:// uk.reuters.com/article/us-china-agriculture-pollutionidUKKBN0N50L720150414 [Access 15.09.2017].

Qiu J. 2010. China faces up to groundwater crisis. Nature, 466: 308

Roberts D. 2015 (October). Creating a Desert in China: Beijing pressures herders to move to the cities. http://www.bloomberg.com/news/articles/2015-1001/china-mongolian-desert-herders-under-pressure-tomove-to-cities

Smil V. 2013. China's environment and natural resources. [In:] Hudson C. 2013. The China Handbook. Routledge. Ch. 14.
Steinbock D. 2010. China's Urbanization: It Has Only Just Begun. http://www.newgeography.com/content/001906china\%E2\%80\%99s-urbanization-it-has-only-just-begun

Sun B., Zhang L.X., Yang L.Z., Zhang F.S., Norse D., Zhu Z.L. 2012. Agricultural Non-Point Source Pollution in China: Causes and Mitigation Measures. Ambio, 41: 370-379. DOI 10.1007/s13280-012-0249-6

Tan D. 2014 (April). The State of China's Agriculture. China Water Risk. http://chinawaterrisk.org/resources/ analysis-reviews/the-state-of-chinas-agriculture/

Tang J., Wu K. 2012. Trend of Acid Rain Over China Since the 1990s. 2013 NOAA ESRL Global monitoring annual conference. David Skaggs Research Center, Boulder, Colorado, Tuesday 21 May 2013. https://www.esrl.noaa. gov/gmd/publications/annual_meetings/2013/abstract s/30-130408-C.pdf [Access 15.09.2017].

Wang M.E., Chen W.P., Peng C. 2016. Risk assessment of Cd polluted paddy soils in the industrial and township areas in Hunan, Southern China. Chemosphere, 144: 346-351. http://dx.doi.org/10.1016/j.chemosphere.2015.09.001

Wee S.L., Jourdan A. 2013. In China, public anger over secrecy on environment. Reuters. http://www.reuters.com/article /us-china-parliament-pollution-idUSBRE92900R20130310 [Access 15 December 2015].

Wong E. 2014. One-Fifth of China's Farmland Is Polluted, State Study Finds. The New York Times. http://www.nytimes. com/2014/04/18/world/asia/one-fifth-of-chinas-farmlandis-polluted-state-report-finds.html?hpw\&rref=science\&_r=1

WWF. 2014. Ecological Footprint and Sustainable Consumption in China. http://www.footprintnetwork. org/images/article_uploads/China_EF_Sustainable_Cons umption_2014_English.pdf

Yan X.D., Gao D., Zhang F., Zeng C., Xiang W., Zhang M. 2013. Relationships between Heavy Metal Concentrations in Roadside Topsoil and Distance to Road Edge Based on Field Observations in the Qinghai-Tibet Plateau. China. Int. J. Environ. Res. Public Health, 10: 762-775. DOI:10.3390/ ijerph10030762

Yang M. 2012. The damaging truth about Chinese fertiliser and pesticide use. China Dialogue. https://www.chinadialogue. net/article/show/single/en/5153-The-damaging-truthabout-Chinese-fertiliser-and-pesticide-use

Zhang D., Huang G., Xu Y., Gong Q. 2015. Waste-to-Energy in China: Key Challenges and Opportunities. Energies, 8(12): 14182-14196.

Zhang J.J., Wang Y., Liu J.S., Liu Q., Zhou Q.H. 2016a. Multivariate and geostatistical analyses of the sources and spatial distribution of heavy metals in agricultural soil in Gongzhuling, Northeast China. J. Soils Sediments, 16, 2: 634-644. DOI: 10.1007/s11368-015-1225-0

Zhang W.J., Jiang F.B., Ou J.F. 2011. Global pesticide consumption and pollution: with China as a focus. Proc. Int. Acad. Ecology Environ. Sci., 1(2): 125-144.

Zhang X.Y., Zhong T.Y., Liu L., Zhang X.M., Cheng M., Li X.H., 2016b. Chromium occurrences in arable soil and its influence on food production in China. Environ. Earth Sci., 75(3): 1-8. DOI: 10.1007/s12665-015-5078-z

Zheng L., Song J., Li C., Gao Y., Geng P., Qu B., Lin L. 2014. Preferential policies promote municipal solid waste (MSW) to energy in China: Current status and prospects. Renew. Sustain. Energy Rev., 36: 135-148. 